\title{
Application of Asiatic Honey Bees (Apis cerana) and Stingless Bees (Trigona laeviceps) as Pollinator Agents of Hot Pepper (Capsicum annuum L.) at Local Indonesia Farm System
}

\author{
Ramadhani Eka Putra, ${ }^{1}$ Agus Dana Permana, ${ }^{1}$ and Ida Kinasih ${ }^{2}$ \\ ${ }^{1}$ School of Life Sciences and Technology, Bandung Institute of Technology, Ganesha Street No. 10, Bandung 40132, Indonesia
}

${ }^{2}$ Department of Biology, Islamic State University Sunan Gunung Djati, Bandung 40614, Indonesia

Correspondence should be addressed to Ramadhani Eka Putra; ramadhani@sith.itb.ac.id

Received 26 September 2014; Accepted 4 December 2014; Published 30 December 2014

Academic Editor: Jan Klimaszewski

Copyright (C) 2014 Ramadhani Eka Putra et al. This is an open access article distributed under the Creative Commons Attribution License, which permits unrestricted use, distribution, and reproduction in any medium, provided the original work is properly cited.

\begin{abstract}
In Indonesia, hot pepper (Capsicum annuum) is one of the most important spices. Despite the fact that high yield cultivars and fertilizers have been applied to increase the annual production of this spice, local farming is always unable to maintain constant production. Studies to find the explanation of this problem mostly focused on pest attack while possibility of low fruit production due to lack of pollination was neglected. In this study, the effect of pollinator visitation to fruit set and quality was assessed by application of two local domesticated honey bees, Asiatic honey bees (Apis cerana) and stingless bees (Trigona laeviceps) as potential pollinator agents at hot pepper plantation. This study found that both bees had similar visitation rate while A. cerana spend less time in flowers. Visitation by A. cerana and Trigona laeviceps improved fruit set, fruit production per plant, average fruit weight, and fruit size. This result confirms the importance of cross pollination for hot pepper production and both species could be used as pollination agent for hot pepper. Advantages and disadvantages for each species as pollination agent for local Indonesia farm system are discussed in this paper.
\end{abstract}

\section{Introduction}

Hot pepper (Capsicum annuum L.) is cultivated and consumed around the world. Its major producers are United States, Mexico, Italy, Japan, India, and Brazil, where this crop has economic importance. Best way to cultivate pepper is in greenhouses which allows production all year round, best management practices, better fruit quality control, lesser or no use of pesticides, earlier harvesting, and superior uniformity of fruits [1]. However, in Indonesia, hot pepper chili usually cultivated at open field where local farmer usually apply best seeds, extensive weed and pest control, and monoculture system in order to obtain high yield. Despite all of these efforts local farmer could not maintain sustained productivity since open field cultivation highly depend on climate condition and ecosystem services, namely, pest control, nutrition cycle, and pollination to produce abundant harvest and good quality fruit [2-5].

Among all available ecosystem services, this study focused on pollination service. Pepper flowers, like those of most cultivated Solanaceae, are pendent from leaf axils, showing a white corolla, five to seven stamens containing 1.0 to $1.5 \mathrm{mg}$ of pollen, and one central style with a round sticky stigma on its top. Anthers are tubular, and dehiscence occurs through lateral opening. Both flower anthesis and anther dehiscence take place in the morning [6]. Although pepper flowers are largely self-pollinated, introducing pollinators could produce beneficial effects on fruit production.

Among pollination agents available in nature, wild insects had been considered as the best pollinator agents and receive huge attention as important component of agriculture systems $[7,8]$. In Indonesia, wild pollinator insects have not 
yet received notice as important component of agriculture system even though some studies have shown the importance of insects as pollinator for some Indonesian perennial and annual crops [9-13]. Lack of understanding on function of particular insects as pollinator agents combined with common practices of synthetic insecticides, removal of wild plants, and destruction of nesting area through plowing significantly reduced population of wild pollinator [14].

In many intensive plantations, to ensure pollination of crop, domesticated bees usually applied as pollinator agents. In case of pepper pollination, best pollinator agent is bumblebees which carried out "buzz pollination," a mechanism related with behavior of bumblebees in order to release pollen of pepper flowers to pollinate female flowers [15-17]. However, bumblebees are not native species of Indonesia and could potentially cause negative effects on native pollinators and plants $[18,19]$.

Alternatively, local bee species, such as Asiatic honey bees (Apis cerana) and various species of stingless bees (Trigona laeviceps), which domesticated by bee farmers for their products (honey, propolis, and wax), may apply as pollinator agents for hot pepper. Previous study showed their possible application as pollinator of tomato flowers, plant with similar flower characteristic with hot pepper flowers [20]. In this study we will evaluate performance of Indonesia domesticated bees as pollination agent of hot pepper and its possible use and concern for application at local farm system.

\section{Materials and Methods}

2.1. Study Area and Research Materials. The pollination experiment was conducted at local farm in North Bandung, West Java, Indonesia. Average daily temperature of study site was $20-25^{\circ} \mathrm{C}$ with humidity $70-75 \%$. For this purpose, thirty red chili plants, planted in pots, were arranged in 3 rows of 10 plants each, with two-meter-wide aisle between the rows. Four colonies ( $\approx 500$ bees per colony) of Trigona laeviceps and four colonies of $A$. cerana ( $\approx 10,000$ bees) were introduced into farm. All colonies were kept in bee hive made from wood and acclimatized for 3 months prior to study.

2.2. Bee Visitation Frequency. Frequency of bee visitation was observed during flowering period by method developed by Klein et al. [12] whereas observation was conducted only at sunny day or $60 \%$ cloudy day between 0900 and 1400 (local time). Observation was conducted with interval of 15 minutes for three consecutive days at different plant. Total number of flowers observed for three days was 100 flowers.

2.3. Bee Pollination Efficiency. In this study, 10-20 flowers from each plant (depend on the number of available flowers), that still not bloomed were randomly selected and tagged. Total number of plants used for each experiment group, explained below, was 10. Each group of flower was bagged with mesh nylon bag (diameter $1 \mathrm{~mm}$ ). Glue was applied at the twig where flowers were located to prevent ant from entering flower.
Bags were kept until fruit production for self-pollinated group. As for bee pollinated group, bags were removed when flower started to bloom. Observation for bee pollination efficiency started from removal of the bag until bee transferred pollen to female flower. After pollination process, flowers were bagged until fruit was produced. This group of treatment was designed as honey bee (HB) and stingless bee (SB) group. Pollination studies of honey bee and stingless bee were conducted in different period. As for control group (NP), bag was not removed from flower until fruit was produced or all flowers has dehiscenced.

Pollination efficiency for each group was measured by

Pollination efficiency

$$
=\frac{\text { Total numbers of flowers that produce fruits }}{\text { Total numbers of observed flowers }} \text {. }
$$

2.4. Fruit Production. Fruit production was measured for every type of pollination. Fruit production was measured by subtracting total number of broken fruits from total fruit produced.

2.5. Fruit Quality. Fruit quality was identified by measuring weight and size of fruit produced from 50 fruits, as soon as they were red in color. The fruits were weighed to the nearest gram and their size was measured to the nearest centimeter.

2.6. Data Analysis. Data was analyzed by statistic program Statistica 8.0 (Statsoft Corp.). Prior to analysis, normality of data was tested. Difference of bee visitation frequency between honey bees and stingless bees was analyzed by $t$ test analysis. Difference of fruit quantity and quality among different pollination types was analyzed by ANOVA and LSD as post hoc test. Significant value for both tests was $P<0.05$.

\section{Results and Discussion}

3.1. Bee Visitation. We found that visitation rate of honey bee to hot pepper flowers similar to stingless bee ( $t$-test analysis, $P>0.05$ ) (Figure 1(a)).

Detail observation on visitation pattern of both species showed that honey bee preferred to visit flowers in early morning while stingless bee visited flowers with relatively constant rate (Figure 1(b)). Early foraging bout by honey bees is probably related with availability of fresh pollen and nectar and attractiveness of flower signal. Hot pepper flowers bloom early in the morning, which provides access to fresh pollen and nectar which is located near base of petal [21]. During midday, when most of flowers were dehisced and provided less resources to be harvested by forager honey bees, most of foragers foraged on different flowering plants (Putra, personal observation). The shifting of foraging force of honey bees among food sources was well reported [22-24].

Stingless bees which are smaller and less aggressive preferred late foraging as they usually took long exploratory flight to find rich, suitable, and economic resources [25]. These bees probably exploited remaining pollen and nectar 
TABLE 1: Average fruit production, weight, and fruit size pollinated by local honey bee, stingless bee, and self-pollination $(N=50)$.

\begin{tabular}{lccc}
\hline Group & Apis cerana & Trigona laeviceps & Self-pollinated \\
\hline Fruit Ppoduction per plant & $22 \pm 3.5^{\mathrm{a}}$ & $20 \pm 3.5^{\mathrm{a}}$ & $17 \pm 3.5^{\mathrm{b}}$ \\
Average fruit weight $(\mathrm{g})$ & $12.55 \pm 4.17^{\mathrm{a}}$ & $11.16 \pm 4.99^{\mathrm{a}}$ & $9.16 \pm 2.99^{\mathrm{b}}$ \\
Fruit size $(\mathrm{cm})$ & $25.16 \pm 9.99^{\mathrm{a}}$ & $24.78 \pm 2.47^{\mathrm{a}}$ & $20.58 \pm 3.47^{\mathrm{b}}$ \\
\hline
\end{tabular}

Different letter indicated statistical difference at $P<0.05$.

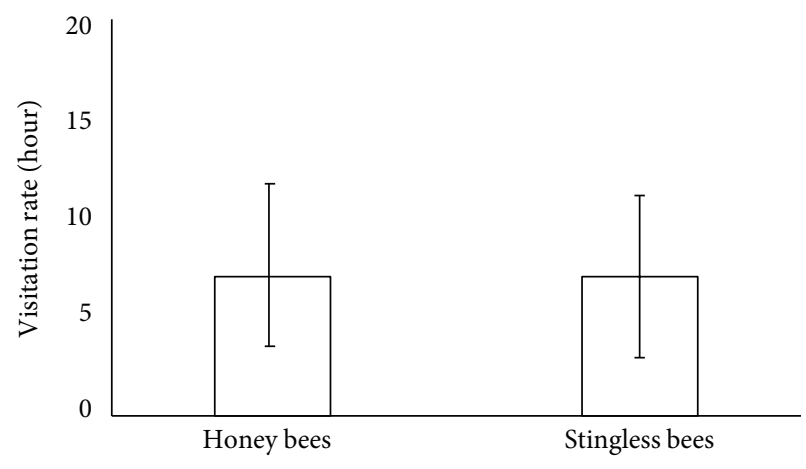

(a)

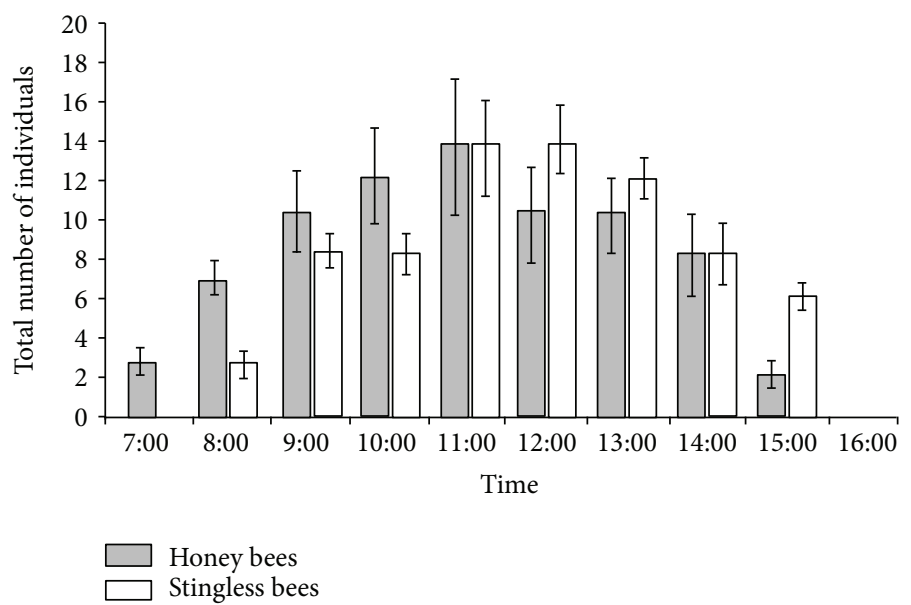

(b)

Figure 1: (a) Visitation rate and (b) visitation pattern of honey bees and stingless bees to hot pepper flowers.

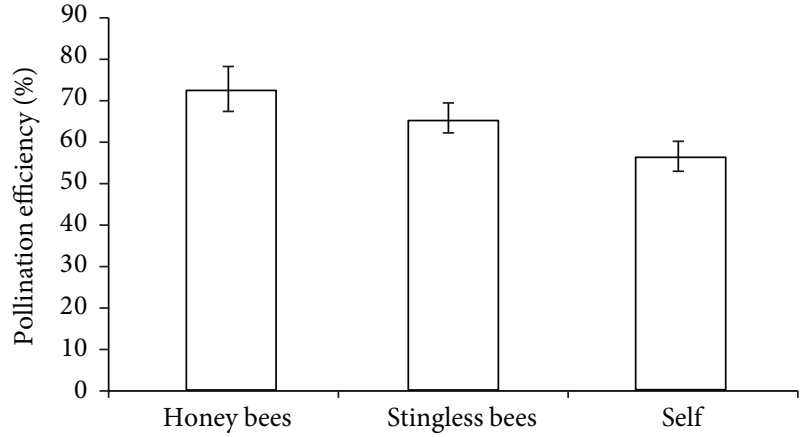

FIGURE 2: Pollination efficiency of hot pepper by honey bee, stingless bee, and self-pollination.

which is inaccessible by honey bees due to their bigger size. Stingless bee also tends to specialize on hot pepper flowers, also known as flower constancy, after competition from honey bee was reduced. Flower constancy is widely found on many species of stingless bee [26-28].

3.2. Pollination Efficiency and Fruit Quality. On average, pollination efficiency of honey bee on hot pepper much higher than stingless bee and pollination assisted by both bee species more efficient than wind pollination ( $t$-test analysis, $P<0.05$ ) (Figure 2).

Total number of fruits produced and quality of hot pepper produces was enhanced significantly by bee pollinated (One way Anova, $P<0.05$ ). Both bee species provide similar

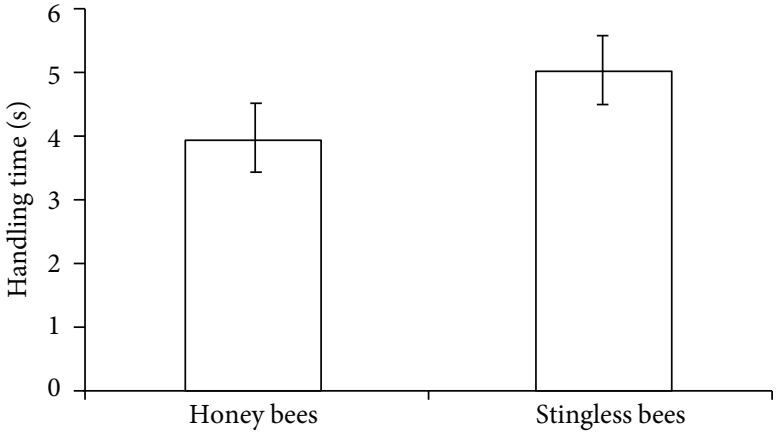

FIGURE 3: Handling time of honey bee and stingless bee on hot pepper flowers.

quality of pollination to hot pepper in terms of fruit produce and size of the fruit (Table 1).

This study confirmed that cross pollination improve pollination efficiency and quality of pepper as also reported by de Oliveira Cruz et al. [1], Roldán Serrano and GuerraSanz [16], and Al-Abbadi [17].

Based on this data, honey bee and stingless bee have great potential as pollinator insect for hot pepper. Even though both species are known for not showing capability to carry out buzz pollination mechanism [15], they seem to provide some disturbances which improve pollination $[29,30]$.

Both species provided pollination in different way which is related to handling time. Honey bees seem more economic species because they spend less time in flower, yet produce better pollination success than stingless bees (Figure 3). 
Higher pollination success could be caused by their bigger size, which produced more disturbances to flowers, and they tend to visit more fertile flowers. On the other hand, higher flower handling and flower constancy of stingless bee increased the possibility of pollen deposited in stigma.

\section{Conclusion}

Both species have several advantages and disadvantages when applied on common Indonesia farming.

Asiatic honey bees have higher pollination efficiency, commonly domesticated by local bee farmers, and have wider foraging area which made them suitable candidate as pollinator agent of hot pepper. However, their aggressive and absconding behavior with high nectar and pollen requirement reduce their value as pollinator agent of small hot pepper plantation farm located nearby human residence and/or plantation with unsustain nectar and pollen resources.

On the other hand, stingless bees more likely to be apply as pollinator agent at plantation located nearby human residence without sustain nectar and pollen resources [31, 32]; small foraging area may provide high visitation rate at small and confined agriculture [30, 33]; their lack of functional sting and less aggressive behavior made them highly suitable for pollination of crops cultivated nearby human dwelling $[34,35]$. Furthermore, these bees foraging on varied plants [36-38] made them applicable as pollinator for varied types of local crops, even though further studies are needed for possible mismatch (see [35]). However, great concern should be addressed on application of insecticide, a common procedure on Indonesia agriculture system, as stingless bee is highly sensitive to common pesticide applied on local farm (Putra, unpublished data).

\section{Conflict of Interests}

The authors declare that there is no conflict of interests regarding the publication of this paper.

\section{Authors' Contribution}

All authors contributed significantly to this work.

\section{Acknowledgment}

This research was funded by Grant STRANAS of DIKTI Indonesia granted to first author.

\section{References}

[1] D. de Oliveira Cruz, B. M. Freitas, L. A. da Silva, E. M. S. da Silva, and I. G. A. Bomfim, "Pollination efficiency of the stingless bee Melipona subnitida on greenhouse sweet pepper," Pesquisa Agropecuaria Brasileira, vol. 40, no. 12, pp. 1197-1201, 2005.

[2] T. H. Ricketts, "Tropical forest fragments enhance pollinator activity in nearby coffee crops," Conservation Biology, vol. 18, no. 5, pp. 1262-1271, 2004.
[3] T. Tscharntke, A. M. Klein, A. Kruess, I. Steffan-Dewenter, and C. Thies, "Landscape perspectives on agricultural intensification and biodiversity-ecosystem service management," Ecology Letters, vol. 8, no. 8, pp. 857-874, 2005.

[4] C. Kremen and R. Chaplin-Kramer, "Insects as providers of ecosystem services: crop pollination and pest control," in Insect Conservation Biology, A. J. A. Stewart, T. R. New, and O. T. Lewis, Eds., pp. 349-382, CABI, Wallingford, UK, 2007.

[5] R. Winfree, N. M. Williams, H. Gaines, J. S. Ascher, and C. Kremen, "Wild bee pollinators provide the majority of crop visitation across land-use gradients in New Jersey and Pennsylvania, USA," Journal of Applied Ecology, vol. 45, no. 3, pp. 793-802, 2008.

[6] A. Dag and Y. Kammer, "Comparison between the effectiveness of honey bee (Apis mellifera) and bumble bee (Bombus terrestris) as pollinators of greenhouse sweet pepper (Capsicum annuum)," American Bee Journal, vol. 141, pp. 447-448, 2001.

[7] K. S. Delaplane and D. F. Mayer, Crop Pollination by Bees, CABI, Wallingford, UK, 2000.

[8] S. S. Greenleaf and C. Kremen, "Wild bee species increase tomato production and respond differently to surrounding land use in Northern California," Biological Conservation, vol. 133, no. 1, pp. 81-87, 2006.

[9] A.-M. Klein, S. A. Cunningham, M. Bos, and I. SteffanDewenter, "Advances in pollination ecology from tropical plantation crops," Ecology, vol. 89, no. 4, pp. 935-943, 2008.

[10] S. Notodimejo, "Influence of growth regulators Dormex, Promalin, foliar fertilizer Algifert and release of honey bees on the development and production of mango in East Java," Agrivita, vol. 18, no. 2, pp. 43-50, 1995.

[11] A.-M. Klein, I. Steffan-Dewenter, and T. Tscharntke, "Fruit set of highland coffee increases with the diversity of pollinating bees," Proceedings of the Royal Society B: Biological Sciences, vol. 270, no. 1518, pp. 955-961, 2003.

[12] A.-M. Klein, I. Steffan-Dewenter, and T. Tscharntke, "Pollination of Coffea canephora in relation to local and regional agroforestry management," Journal of Applied Ecology, vol. 40, no. 5, pp. 837-845, 2003.

[13] R. Olschewski, T. Tscharntke, P. C. Benítez, S. Schwarze, and A.M. Klein, "Economic evaluation of pollination services comparing coffee landscapes in Ecuador and Indonesia," Ecology and Society, vol. 11, no. 1, article no. 7, 2006.

[14] C. Kremen and R. Chaplin-Kramer, "Insects as providers of ecosystem services: crop pollination and pest control," in Insect Conservation Biology: Proceedings of the Royal Entomological Society's 23rd Symposium, A. J. A. Stewart, T. R. New, and O. T. Lewis, Eds., pp. 349-382, CABI, Wallington, UK, 2007.

[15] S. L. Buchmann, "Buzz pollination in angiosperms," in Handbook of Experimental Pollination Biology, C. E. Jones and R. J. Little, Eds., pp. 73-114, Van Nostrand Reinhold, New York, NY, USA, 1983.

[16] A. Roldán Serrano and J. M. Guerra-Sanz, "Quality fruit improvement in sweet pepper culture by bumblebee pollination," Scientia Horticulturae, vol. 110, no. 2, pp. 160-166, 2006.

[17] S. Y. A. Al-Abbadi, "Efficiency of different pollination treatments on solanaceae yields grown in plastic house," Journal of Biological Sciences, vol. 9, no. 5, pp. 464-469, 2009.

[18] A. B. Hingston and P. B. McQuillan, "Displacement of Tasmanian native megachilid bees by the recently introduced bumblebee Bombus terrestris (Linnaeus, 1758) (Hymenoptera: Apidae)," Australian Journal of Zoology, vol. 47, no. 1, pp. 59-65, 1999. 
[19] D. Goulson, "Effects of introduced bees on native ecosystem," Annual Review of Ecology, Evolution, and Systematics, vol. 34, pp. 1-26, 2003.

[20] R. E. Putra and I. Kinasih, "Efficiency of local Indonesia honey bees (Apis cerana L.) and stingless bee (Trigona iridipennis) on Tomato (Lycopersicon esculentum Mill.) pollination," Pakistan Journal of Biological Sciences, vol. 17, no. 1, pp. 86-91, 2013.

[21] S. Vogel, "Remarkable nectaries: structure, ecology, organophyletic perspectives. III. Nectar ducts," Flora, vol. 193, no. 2, pp. 113-131, 1998.

[22] T. D. Seeley, S. Camazine, and J. Sneyd, "Collective decisionmaking in honey bees: how colonies choose among nectar sources," Behavioral Ecology and Sociobiology, vol. 28, no. 4, pp. 277-290, 1991.

[23] B. Granovskiy, T. Latty, M. Duncan, D. J. T. Sumpter, and M. Beekman, "How dancing honey bees keep track of changes: the role of inspector bees," Behavioral Ecology, vol. 23, no. 3, pp. 588-596, 2012.

[24] A. E. Wagner, B. N. Van Nest, C. N. Hobbs, and D. Moore, "Persistence, reticence and the management of multiple time memories by forager honey bees," The Journal of Experimental Biology, vol. 216, no. 7, pp. 1131-1141, 2013.

[25] C. S. Danaraddi, Studies on stingless bee, Trigona iridipennis Smith with special reference to foraging behaviour and melissopalynology at Dhawad, Karnataka [Master of science thesis], College of Agricultural Science, Dhawad, India, 2007.

[26] T. Inoue, S. Salmah, I. Abbas, and E. Yusuf, "Foraging behavior of individual workers and foraging dynamics of colonies of three Sumatran stingless bees," Researches on Population Ecology, vol. 27, no. 2, pp. 373-392, 1985.

[27] M. Ramalho, A. Kleinert-Giovannini, and V. ImperatrizFonseca, "Important bee plants for stingless bees (Melipona and Trigonini) and Africanized honeybees (Apis mellifera) in neotropical habitats: a review," Apidologie, vol. 21, no. 5, pp. 469$488,1990$.

[28] O. Cauich, J. J. G. Quezada-Euán, J. O. Macias-Macias, V. Reyes-Oregel, S. Medina-Peralta, and V. Parra-Tabla, "Behavior and pollination efficiency of Nannotrigona perilampoides (Hymenoptera: Meliponini) on greenhouse tomatoes (Lycopersicon esculentum) in subtropical México," Journal of Economic Entomology, vol. 97, no. 2, pp. 475-481, 2004.

[29] A. Jarlan, D. de Oliveira, and J. Gingras, "Pollination by Eristalis tenax (Diptera: Syrphidae) and seed set of greenhouse sweet pepper," Horticultural Entomology, vol. 90, pp. 1646-1649, 1997.

[30] A. Raw, "Foraging behavior of wild bees at hot pepper flowers (Capsicum annuum) and its possible influence on cross pollination," Annals of Botany, vol. 85, no. 4, pp. 487-492, 2000.

[31] D. R. Campbell and A. F. Motten, "The mechanism of competition between two forest herbs," Ecology, vol. 66, no. 2, pp. 554563, 1985.

[32] C. T. Ivey, P. Martinez, and R. Wyatt, "Variation in pollinator effectiveness in swamp milkweed, Asclepias incarnata (Apocynaceae)," American Journal of Botany, vol. 90, no. 2, pp. 214-225, 2003.

[33] T. Kakutani, T. Inoue, T. Tezuka, and Y. Maeta, "Pollination of strawberry by the stingless bee, Trigona minangkabau, and the honey bee, Apis mellifera: an experimental study of fertilization efficiency," Researches on Population Ecology, vol. 35, no. 1, pp. 95-111, 1993.

[34] T. A. Heard, "The role of stingless bees in crop pollination," Annual Review of Entomology, vol. 44, pp. 183-206, 1999.
[35] E. J. Slaa, L. A. Sánchez Chaves, K. S. Malagodi-Braga, and F. E. Hofstede, "Stingless bees in applied pollination: practice and perspectives," Apidologie, vol. 37, no. 2, pp. 293-315, 2006.

[36] D. W. Roubik, Ecology and Natural History of Tropical Bees, Cambridge University Press, Cambridge, UK, 1989.

[37] M. Ramalho, T. C. Giannini, K. S. Malagodibraga, and V. L. Imperatriz-Fonseca, "Pollen harvest by stingless bee foragers (Hymenoptera, Apidae, Meliponinae)," Grana, vol. 33, pp. 239244, 1994.

[38] J. C. Biesmeijer, E. J. Slaa, M. S. de Castro, B. F. Viana, A. Kleinert, and V. L. Imperatriz-Fonseca, "Connectance of Brazilian social bee-food plant networks is influenced by habitat, but not by latitude, altitude or network size," Biota Neotropica, vol. 5, no. 1, pp. 85-93, 2005. 

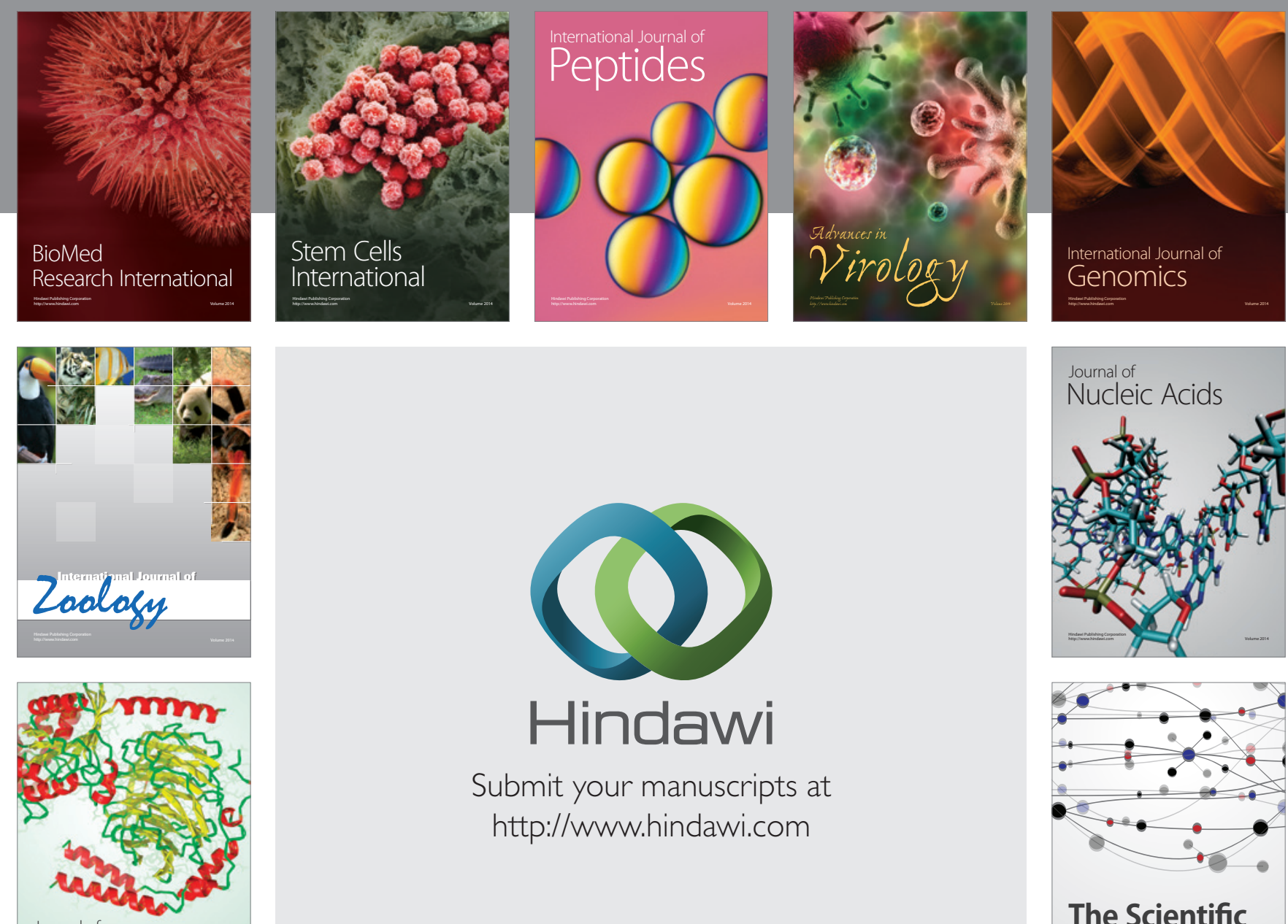

Submit your manuscripts at

http://www.hindawi.com

Journal of
Signal Transduction
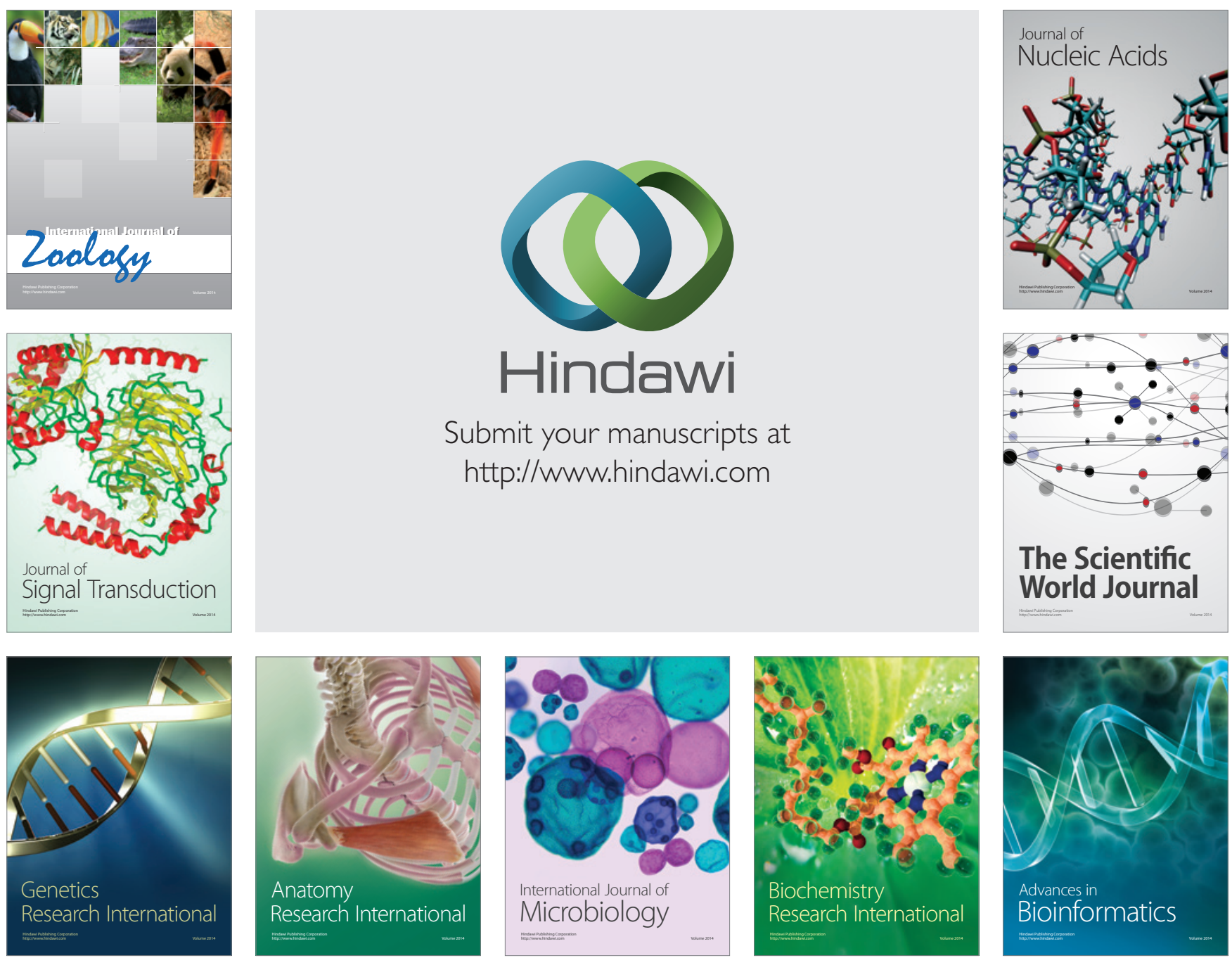

The Scientific World Journal
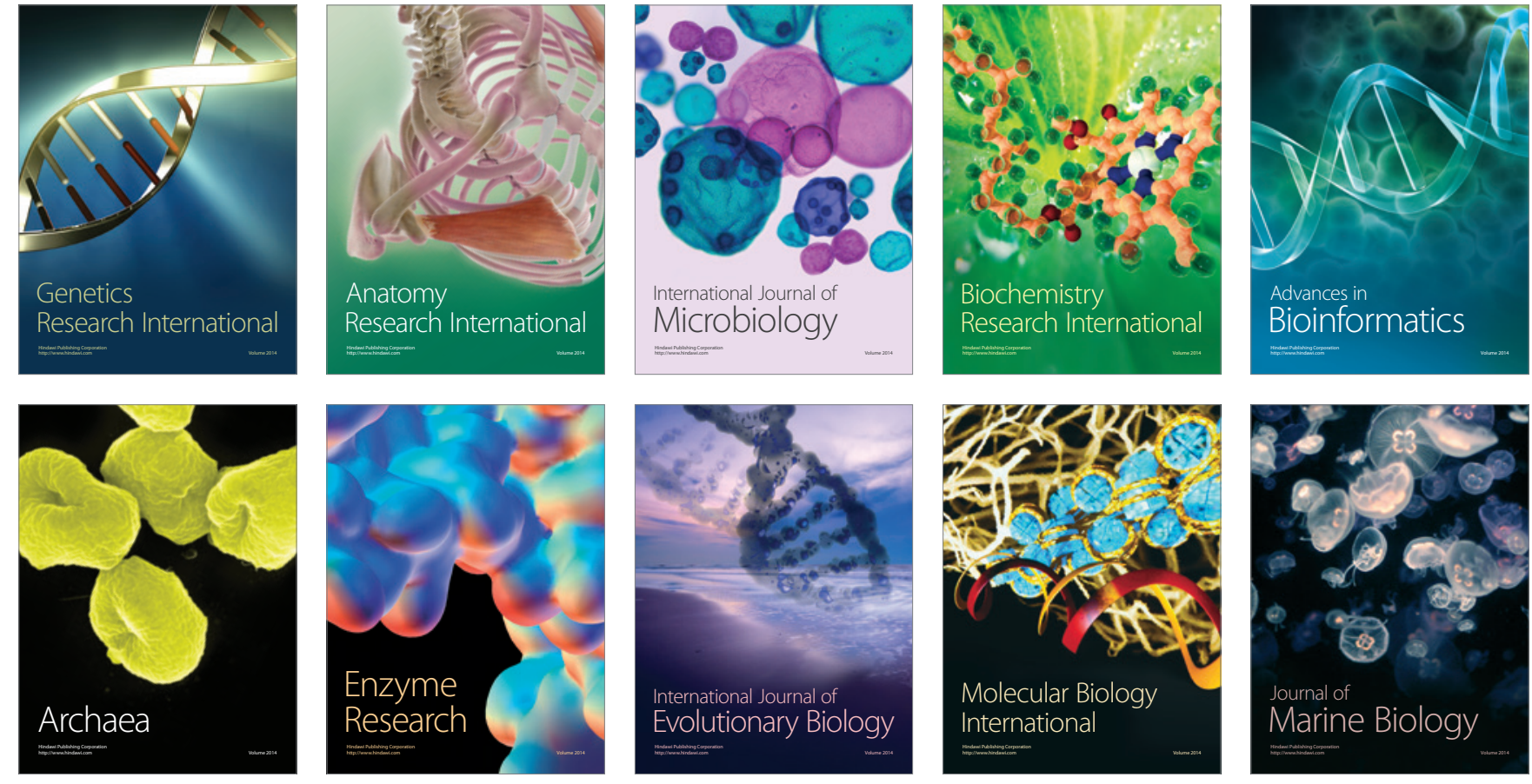